\title{
CONTROLLING PARTNERING RELATIONS IN CONSTRUCTION OPERATIONS USING FUZZY REASONING
}

\section{E. RADZISZEWSKA-ZIELINA ${ }^{1}$, B. SZEWCZYK ${ }^{2}$}

\begin{abstract}
The article presents the use of the Mamdani fuzzy reasoning model to develop a proposal of a system controlling partnering relations in construction projects. The system input variables include: current assessments of particular partnering relation parameters, the weights of these parameters' impact on time, cost, quality and safety of implementation of construction projects, as well as the importance of these project assessment criteria for its manager. For each of the partnering relation parameters, the project's manager will receive control recommendations. Moreover, the parameter to be improved first will be indicated. The article contains a calculation example of the system's operations.
\end{abstract}

Keywords: construction projects, control system, fuzzy reasoning, Mamdani model, partnering relations

\section{INTRODUCTION}

Partnering, as an approach for management of construction projects, has gained popularity in recent years, mostly because of the benefits arising from its use which is indicated by the publications dedicated to this topic, such as $[2,3,4,7,16]$. Among the most noticeable benefits of partnering, the publications mention: limiting the number of disputes, improvement of communication between the project's participants, decreased exposition to risk or higher client's satisfaction. Apart from these, there are also measurable benefits being indicated which directly translate to financial success of the

\footnotetext{
${ }^{1}$ Ph.D., Cracow University of Technology, Faculty of Civil Engineering, ul. Warszawska 24, 31-155 Cracow, Poland, e-mail: eradzisz@izwbit.pk.edu.pl

${ }^{2}$ M.Sc., Cracow University of Technology, Faculty of Civil Engineering, ul. Warszawska 24, 31-155 Cracow, Poland, e-mail: bszewczyk@izwbit.pk.edu.pl
} 
projects, such as: reduction of time and project implementation cost, an increase in the quality of conducted works, a reduction of project time or lower supervision costs.

Having considered the construction companies' orientation on measurable benefits, the article contains a proposal of a system supporting the management of construction projects through the expansion of partnering relations in the areas which provide the greatest benefits in relation to time, cost, quality and safety of the construction projects implementation. Both Kosecki in his article [8], referring to Masterman's study [9], and Strzelecka et al. in the publication [15], referring to Mingus' study [10], list precisely time, cost and quality as generally accepted indicators of a project's success. On the other hand, safety is a very significant factor because it provides health and life protection over the course of the construction works.

The developed controlling system will be dedicated to being used by the project's manager, in the person of - in different implementation systems - the general contractor, project manager or construction manager. It is the project participant who mainly cares about meeting the set deadline or providing adequate quality of works and safety at the construction site. As in the case of every entrepreneur, he/she tries to achieve this while maintaining a low level of costs. Again, it is the participant who, while implementing the project, maintains direct contact with the contractors (subcontractors), the suppliers of materials and construction equipment, the investor, and also the designer, which creates great possibilities for him/her to develop partnering relations. The system to control them will be the first tool of this type. Methods supporting construction project management through the development of partnering relations presented so far have been limited only to assessment and monitoring of the partnering level in the project $[1,5,6,17]$ or have concerned controlling, yet the controlling which presents strategic character in construction companies [12].

\section{PROPOSAl OF A SYSTEM CONTROLLING PARTNERING RELATIONS}

\subsection{SYSTEM DESCRIPTION}

The controlling system will make use of partnering relations parameters assigned to four types of partnering cooperation in the implementation of constructions projects, as identified in the article [13]. These types are distinguished because of the project participants with whom the project's manager cooperates most frequently and they include: cooperation with the contractors (subcontractors), the designer, the suppliers and the investor. Parameters of partnering relations, as a part of the cooperation between the project's manager and contractors/subcontractors, include: 
participation in construction organisation, sharing non-material, material and human resources, effective communication, maintaining the set standards and following the rules of behaviour, keeping to the agreed payment deadlines and amounts, frequency of dispute occurrence and time needed to solve them and adaptability to changes. Partnering relation parameters, as a part of the project's manager's cooperation with the designer, include: time needed to reply to propositions of changes in the project, time needed to react to project's problems and adaptation of design solutions (additional works, changes in works) to the contractor's capabilities. Partnering relation parameters, as a part of the project's manager's cooperation with the suppliers, include: providing quality of materials and equipment, making shipments on time and current technical support. Partnering relation parameters, as a part of the project's manager's cooperation with the investor, include: negotiating the site establishment, keeping to the agreed payment deadlines and amounts, availability of the investor's representatives during acceptance of works, frequency of dispute occurrences and time needed to solve them.

As part of the partnering relation parameters are of an unmeasurable character (e.g. maintaining the set standards and following the rules of behaviour in terms of cooperation with contractors), fuzzy sets theory has been used in order to control partnering relations in construction projects and has been applied in the case of shaping the phenomenons which are naturally perceived as qualityrelated and inaccurate terms (e.g. the good assessment of partnering relations in the context of a specific parameter, a high parameter's impact on the project completion time). The article uses a fuzzy model based on Mamdani reasoning described in publication [11], which is used to find conclusions on the basis of crisp values of input variables and with the use of a developed rule base. It is specific to the Mamdani model that both the IF part of the rule base as well as the THEN part are fuzzy.

The reasoning system's functioning can be divided into three fundamental processes, conducted for each combination of the partnering relation parameter and analysed construction project's assessment criterion (time, cost, quality, safety):

- Fuzzification: determining the membership rate of $\mu_{\mathrm{A}}$ in the fuzzy sets of input variables (assessment of partnering relation parameters, weights of the impact of particular partnering relation parameters on analysed project assessment criterion, weights of project assessment criteria);

- Inference: calculating the resulting membership function $\mu_{\mathrm{wyn}}(\mathrm{y})$;

- Defuzzification: calculating the $\mathrm{y}^{*}$ crisp output value. 


\subsection{FUZZIFICATION}

Assessments of partnering relation parameters on a five-point scale will be used for control - with grade 5 meaning very good and grade 1 meaning very poor. Apart from the assessments of partnering relation parameters $\left(\mathrm{x}_{1}\right)$, which will be determined by the operator, input variables of the reasoning system will also include weights of the impact of particular partnering relation parameters on the aforementioned project assessment criteria - time, cost, quality and safety $\left(\mathrm{x}_{2}\right)$. They will be formed, based on performed researches, by the slopes of regression function presented in the article [14]. The correlations between the partnering relations level in the context of particular parameters and their impact on time, cost, quality and safety of the construction project's implementation for which the value of at least one of the analysed correlation coefficients is lower than 0.6 , the weights of the partnering relation parameter's impact on project assessment criteria will take the value 0 . Furthermore, the input variables will include, determined by the operator in the five-point scale, weights of the analysed project assessment criterion $\left(\mathrm{x}_{3}\right)$, according to Table 1 . This will enable defining of how important are time, cost, quality and safety of the project implementation for the project's manager.

Table 1. Weights of project assessment criteria in linguistic form and five-point scale;

source: own elaboration

\begin{tabular}{|c|c|c|c|c|c|}
\hline $\begin{array}{c}\text { Weight of the project } \\
\text { assessment criterion }\end{array}$ & $\begin{array}{c}\text { very low } \\
\text { importance }\end{array}$ & $\begin{array}{c}\text { low } \\
\text { importance }\end{array}$ & $\begin{array}{c}\text { medium } \\
\text { importance }\end{array}$ & important & $\begin{array}{c}\text { very } \\
\text { important }\end{array}$ \\
\hline Value in numerical scale & 1 & 2 & 3 & 4 & 5 \\
\hline
\end{tabular}

Fig. 1, 2 and 3 present membership functions of fuzzy sets for input variables. Triangular membership functions were used.

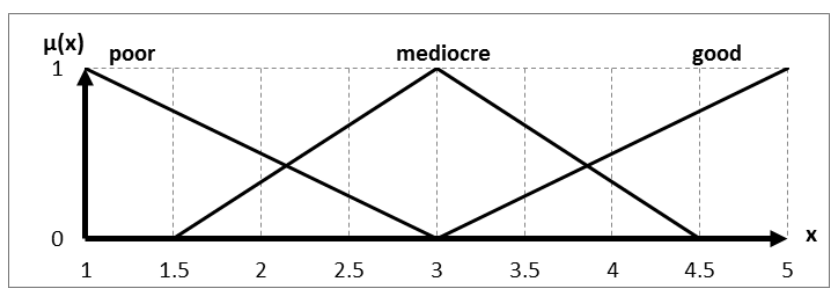

Fig. 1. Membership functions for assessment of partnering relation parameters; source: own elaboration 


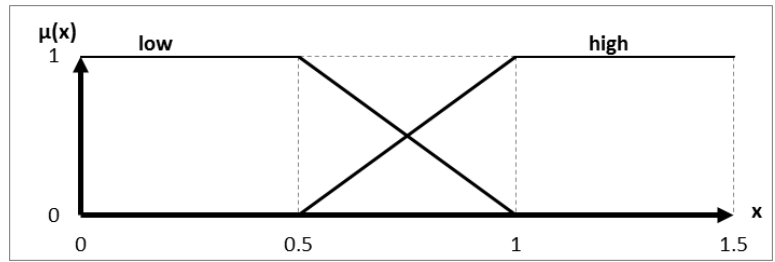

Fig. 2. Membership functions for weights of partnering relation parameters' impact on project assessment criteria; source: own elaboration

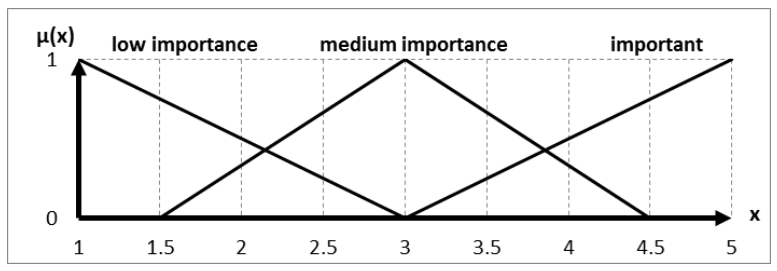

Fig. 3. Membership functions for weights of project assessment criteria; source: own elaboration

For crisp values of input variables $\left(\mathrm{x}_{1}^{*}-\right.$ assessment of partnering relation parameter, $\mathrm{x}_{2}^{*}-$ weight of partnering relation parameter's impact on project assessment criterion, $\mathrm{x}_{3}^{*}$ - weight of project assessment criterion), the membership rate for a particular fuzzy set is determined:

$\mu_{\mathrm{A}_{1}^{1}}\left(\mathrm{x}_{1}^{*}\right)$ - rate of partnering relation parameter assessment's membership in the "poor" set; $\mu_{\mathrm{A}_{2}^{1}}\left(\mathrm{x}_{1}^{*}\right)$ - rate of partnering relation parameter assessment's membership in the "mediocre" set; $\mu_{\mathrm{A}_{3}^{1}}\left(\mathrm{x}_{1}^{*}\right)$ - rate of partnering relation parameter assessment's membership in the "good" set; $\mu_{\mathrm{A}_{1}^{2}}\left(\mathrm{x}_{2}^{*}\right)$ - rate of partnering relation parameter weight of impact membership in the "low" set; $\mu_{\mathrm{A}_{2}^{2}}\left(\mathrm{x}_{2}^{*}\right)$ - rate of partnering relation parameter weight of impact membership in the "high" set; $\mu_{\mathrm{A}_{1}^{3}}\left(\mathrm{x}_{3}^{*}\right)$ - rate of project assessment criterion weight's membership in the "low importance" set; $\mu_{\mathrm{A}_{2}^{3}}\left(\mathrm{x}_{3}^{*}\right)$ - rate of project assessment criterion weight's membership in the "medium importance" set; $\mu_{\mathrm{A}_{3}^{3}}\left(\mathrm{x}_{3}^{*}\right)$ - rate of project assessment criterion weight's membership in the "important" set. It can be noticed that one input variable can belong to two fuzzy sets, for example: rates of membership in the "poor" and "mediocre" sets for assessment of partnering relation parameter on 
the level of $x_{1}^{*}=2$ are respectively $\mu_{\mathrm{A}_{1}^{1}}(2)=0.50$ and $\mu_{\mathrm{A}_{2}^{1}}(2)=0.33$ (see the example in section 3).

\subsection{INFERENCE}

Two fundamental elements of the inference engine include:

- rule base,

- inference mechanism.

The rule base was developed for each combination of partnering relation parameter and project assessment criterion. When developing the rules, the following conditions were met. If the assessment of the partnering relation parameter is good, then the level of partnering relations should be maintained. Cooperation in the context of a specific partnering relation parameter should be maintained at the specific level in the case when the specific project assessment criterion presents low importance for the manager, or presents medium importance and the impact of the partnering relation parameter on this criterion is low. In the case when the project assessment criterion is described as presenting medium importance and the partnering relation parameter is on a poor level, or when the project assessment criterion is described as important and the partnering relation parameter is on a medium level, it should be improved. It is similar in the case of a medium partnering relation parameter assessment with project assessment criterion presenting medium importance and high impact of the partnering relation parameter on this criterion. In the case of the partnering relation parameter being assessed as poor and the project assessment criterion as important, it should be improved immediately, if it has high impact on this criterion or improves it in the case of low impact. The developed rule base presents a conjunctional form of the "if-andthen" type. It comprises 18 rules for each combination of the partnering relation parameter and project assessment criterion, providing a total of 1296 rules. 18 general rules of the base are presented below:

R1: If $\mathbf{x}_{1}=$ poor and $\mathbf{x}_{2}=$ low and $\mathbf{x}_{3}=$ important then $\mathbf{y}=$ improve

R2: If $x_{1}=$ average and $x_{2}=$ low and $x_{3}=$ important then $y=$ improve

R3: If $\mathbf{x}_{1}=\operatorname{good}$ and $\mathbf{x}_{2}=$ low and $\mathbf{x}_{3}=$ important then $\mathbf{y}=$ keep

R4: If $\mathbf{x}_{1}=$ poor and $\mathbf{x}_{2}=$ low and $\mathbf{x}_{3}=$ average importance then $\mathbf{y}=$ improve

R5: If $\mathbf{x}_{1}=$ average and $\mathbf{x}_{2}=$ low and $\mathbf{x}_{3}=$ average importance then $\mathbf{y}=$ keep

R6: If $\mathbf{x}_{1}=\operatorname{good}$ and $\mathbf{x}_{2}=$ low and $\mathbf{x}_{3}=$ average importance then $\mathbf{y}=$ keep

R7: If $\mathbf{x}_{1}=$ poor and $\mathbf{x}_{2}=$ low and $\mathbf{x}_{3}=$ low importance then $\mathbf{y}=\mathbf{k e e p}$ 
R8: If $\mathbf{x}_{1}=$ average and $\mathbf{x}_{2}=$ low and $\mathbf{x}_{3}=$ low importance then $\mathbf{y}=$ keep

R9: If $\mathbf{x}_{1}=$ good and $\mathbf{x}_{2}=$ low and $\mathbf{x}_{3}=$ low importance then $\mathbf{y}=$ keep

R10: If $\mathbf{x}_{1}=$ poor and $\mathbf{x}_{2}=$ high and $\mathbf{x}_{3}=$ important then $\mathbf{y}=$ improve immediately

R11: If $\mathbf{x}_{1}=$ average and $\mathbf{x}_{2}=$ high and $\mathbf{x}_{3}=$ important then $\mathbf{y}=$ improve

R12: If $\mathbf{x}_{1}=\operatorname{good}$ and $\mathbf{x}_{2}=$ high and $\mathbf{x}_{3}=$ important then $\mathbf{y}=$ keep

R13: If $\mathbf{x}_{1}=$ poor and $\mathbf{x}_{2}=$ high and $x_{3}=$ average importance then $\mathbf{y}=$ improve

R14: If $\mathbf{x}_{1}=$ average and $\mathbf{x}_{2}=$ high and $\mathbf{x}_{3}=$ average importance then $\mathbf{y}=$ improve

R15: If $\mathbf{x}_{1}=\operatorname{good}$ and $\mathbf{x}_{2}=$ high and $\mathbf{x}_{3}=$ average importance then $\mathbf{y}=$ keep

R16: If $\mathbf{x}_{1}=$ poor and $\mathbf{x}_{2}=$ high and $\mathbf{x}_{3}=$ low importance then $\mathbf{y}=$ keep

R17: If $\mathbf{x}_{1}=$ average and $\mathbf{x}_{2}=$ high and $\mathbf{x}_{3}=$ low importance then $\mathbf{y}=$ keep

R18: If $\mathbf{x}_{1}=\operatorname{good}$ and $\mathbf{x}_{2}=$ high and $\mathbf{x}_{3}=$ low importance then $\mathbf{y}=$ keep

Output variable is a conclusion which can assume the following indications with regard to the particular partnering relation parameter: keep, improve, and improve immediately. Fig. 4 presents membership functions for fuzzy sets of the output variable.

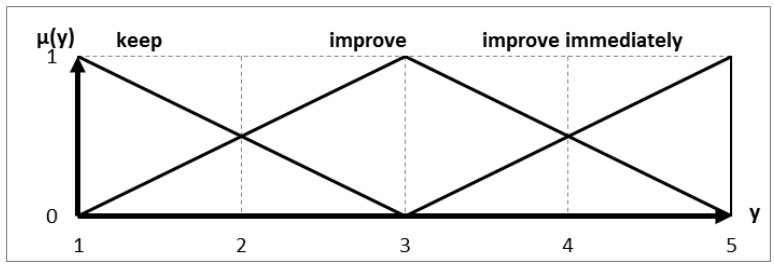

Fig. 4. Membership functions for the output variable; source: own elaboration

Inference mechanism is used to determine the resulting membership function $\mu_{\mathrm{wyn}}(\mathrm{y})$. In the first step, the degree of meeting the conditions for each of the rules is determined while using the AND operator in the form of min function, according to the formula:

$$
\mathrm{h}=\min \left(\mu_{\mathrm{A}^{1}}\left(\mathrm{x}_{1}^{*}\right), \mu_{\mathrm{A}^{2}}\left(\mathrm{x}_{2}^{*}\right), \mu_{\mathrm{A}^{3}}\left(\mathrm{x}_{3}^{*}\right)\right)
$$

where:

$\mu_{\mathrm{A}^{1}}\left(\mathrm{x}_{1}^{*}\right), \mu_{\mathrm{A}^{2}}\left(\mathrm{x}_{2}^{*}\right), \mu_{\mathrm{A}^{3}}\left(\mathrm{x}_{3}^{*}\right)$ - input variables' rates of membership for fuzzy sets in the rule.

Non-activated rules $(\mathrm{h}=0)$ do not take part in the inference from that point. Next, the modified conclusion membership functions of particular rules are determined, using the formula: 


$$
\mu_{\mathrm{B}^{*}}(\mathrm{y})=\min \left(\mathrm{h}, \mu_{\mathrm{B}}(\mathrm{y})\right)
$$

where:

$\mu_{\mathrm{B}}(\mathrm{y})$ - function of rule conclusion membership.

Determining the resulting membership function $\mu_{\mathrm{wyn}}(\mathrm{y})$ is performed through the aggregation of the modified membership functions $\mu_{\mathrm{B}^{*}}(\mathrm{y})$ of conclusions of specific rules using the OR operator in the form of the max function, using the formula:

$$
\mu_{\mathrm{wyn}}(\mathrm{y})=\max \left(\mu_{\mathrm{B} 1^{*}}(\mathrm{y}), \mu_{\mathrm{B} 2^{*}}(\mathrm{y}), \ldots, \mu_{\mathrm{Bm}^{*}}(\mathrm{y})\right)
$$

where:

$\mu_{\mathrm{B} 1^{*}}(\mathrm{y}), \mu_{\mathrm{B} 2^{*}}(\mathrm{y}), \ldots, \mu_{\mathrm{Bm}^{*}}(\mathrm{y})$ - modified activated rule conclusion's membership functions.

\subsection{DEFUZZIFICATION}

In order to perform defuzzification, the centre of gravity method was selected:

$$
y^{*}=\frac{\int_{a}^{b} y \cdot \mu_{w y n}(y) d y}{\int_{a}^{b} \mu_{w y n}(y) d y}
$$

where:

$\mathrm{y}^{*}-$ is the output crisp value of conclusion for a single partnering relation parameter combination and project assessment criterion.

Based on the crisp output value, the conclusion will be determined for which the membership function value in $\mathrm{y}=\mathrm{y}^{*}$ will be maximum $\max \left(\mu_{\mathrm{B} 1}\left(\mathrm{y}^{*}\right), \mu_{\mathrm{B} 2}\left(\mathrm{y}^{*}\right), \mu_{\mathrm{B} 3}\left(\mathrm{y}^{*}\right)\right)$.

Therefore, for each parameter of partnering relation there will be 4 conclusions ascertained, one with regard to each project assessment criterion. Eventually, the most radical out of the 4 conclusions will be chosen, the least radical being the "keep" conclusion and the most radical being the "improve immediately" conclusion. Apart from that, the parameter that requires improvement first will be chosen. Among the partnering relation parameters with the "improve immediately" 
conclusion, the parameter with the highest impact weight used to determine the conclusion will be chosen, therefore its improvement will result in the greatest benefit in relation to the project assessment criterion described as "important" or "very important".

\section{Calculation eXample}

The example of the controlling system operation presented below is related to the cooperation between the project's manager and the designer in the context of adaptation of design solutions (additional works, changes in works) to the contractor's capabilities and time of project

\section{implementation.}

\section{Example values of input variables}

- Assessment of the partnering relation parameter: $\mathbf{x}_{\mathbf{1}}^{*}=\mathbf{2}$

- Weight of the partnering relation parameter's impact on project assessment criterion [14]: $\mathrm{x}_{2}^{*}=\mathbf{0 . 7 7 5}$

- Weight of the project assessment criterion: very important $\mathbf{x}_{\mathbf{3}}^{*}=\mathbf{5}$

\section{Fuzzification}

In Fig. 5 the fuzzification process for crisp values of input variables has been presented.
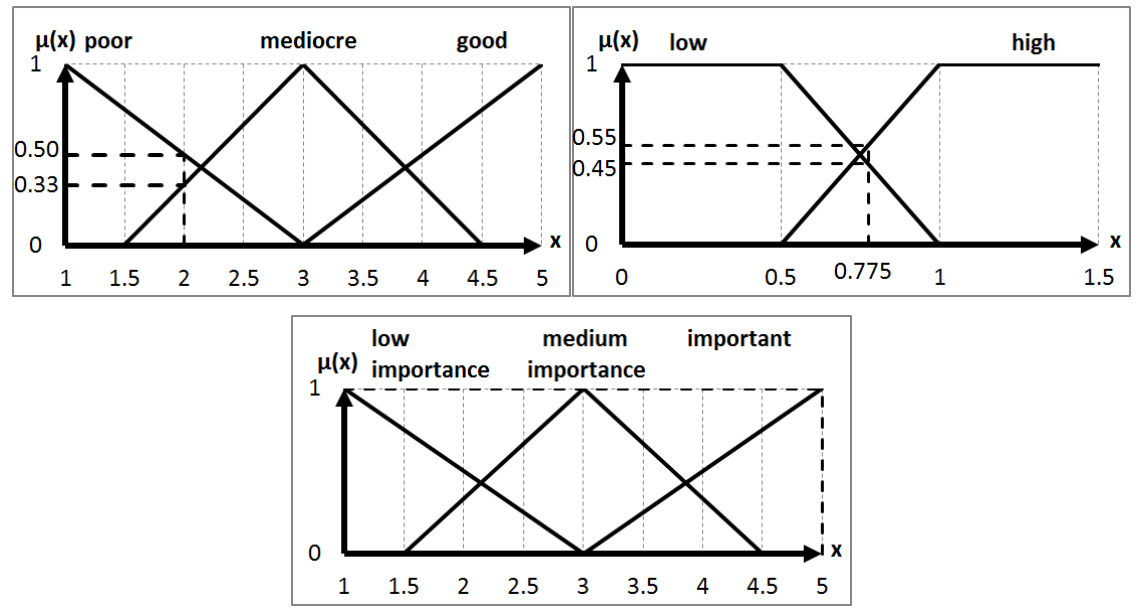

Fig. 5. Illustration of the fuzzification process for crisp values of input variables; source: own elaboration

rate of partnering relation parameter assessment's membership in the "poor" set $\mu_{\mathrm{A}_{1}^{1}}(2)=0.50$ 
rate of partnering relation parameter assessment's membership in the "mediocre" set $\mu_{\mathrm{A}_{2}^{1}}(2)=0.33$ rate of partnering relation parameter assessment's membership in the "good" set $\mu_{\mathrm{A}_{3}^{1}}(2)=0$ rate of partnering relation parameter weight of impact membership in the "low" set $\mu_{\mathrm{A}_{1}^{2}}(0.775)=0.45$

rate of partnering relation parameter weight of impact membership in the "high" set $\mu_{\mathrm{A}_{2}^{2}}(0.775)=0.55$

rate of project assessment criterion weight's membership in the "low importance" set $\mu_{\mathrm{A}_{1}^{3}}(5)=0$ rate of project assessment criterion weight's membership in the "medium importance" set $\mu_{\mathrm{A}_{2}^{3}}(5)=0$

rate of project assessment criterion weight's membership in the "important" set $\mu_{\mathrm{A}_{3}^{3}}(5)=1$

\section{Inference}

The following rules will be activated:

If $\mathbf{x}_{1}=$ poor and $\mathbf{x}_{2}=$ low and $\mathbf{x}_{3}=$ important then $\mathbf{y}=$ improve

If $x_{1}=$ poor and $x_{2}=$ high and $x_{3}=$ important then $y=$ improve immediately

If $x_{1}=$ average and $x_{2}=$ low and $x_{3}=$ important then $y=$ improve

If $x_{1}=$ average and $x_{2}=$ high and $x_{3}=$ important then $y=$ improve

The degree of meeting the conditions of each rules, presented in respective order:

$$
\begin{aligned}
& \mathrm{h}=\min \left(\mu_{\mathrm{A}^{1}}\left(\mathrm{x}_{1}^{*}\right), \mu_{\mathrm{A}^{2}}\left(\mathrm{x}_{2}^{*}\right), \mu_{\mathrm{A}^{3}}\left(\mathrm{x}_{3}^{*}\right)\right)=\min (0.50,0.45,1)=0.45 \\
& \mathrm{~h}=\min \left(\mu_{\mathrm{A}^{1}}\left(\mathrm{x}_{1}^{*}\right), \mu_{\mathrm{A}^{2}}\left(\mathrm{x}_{2}^{*}\right), \mu_{\mathrm{A}^{3}}\left(\mathrm{x}_{3}^{*}\right)\right)=\min (0.50,0.55,1)=0.50 \\
& \mathrm{~h}=\min \left(\mu_{\mathrm{A}^{1}}\left(\mathrm{x}_{1}^{*}\right), \mu_{\mathrm{A}^{2}}\left(\mathrm{x}_{2}^{*}\right), \mu_{\mathrm{A}^{3}}\left(\mathrm{x}_{3}^{*}\right)\right)=\min (0.33,0.45,1)=0.33 \\
& \mathrm{~h}=\min \left(\mu_{\mathrm{A}^{1}}\left(\mathrm{x}_{1}^{*}\right), \mu_{\mathrm{A}^{2}}\left(\mathrm{x}_{2}^{*}\right), \mu_{\mathrm{A}^{3}}\left(\mathrm{x}_{3}^{*}\right)\right)=\min (0.33,0.55,1)=0.33
\end{aligned}
$$


Modified conclusion membership functions of particular rules are presented in Fig. 6, 7.

$$
\mu_{\mathrm{B} 2}(\mathrm{y})=\min \left(0.45, \mu_{\mathrm{B} 2}(\mathrm{y})\right) \quad \mu_{\mathrm{B} 3^{*}}(\mathrm{y})=\min \left(0.50, \mu_{\mathrm{B} 3}(\mathrm{y})\right)
$$
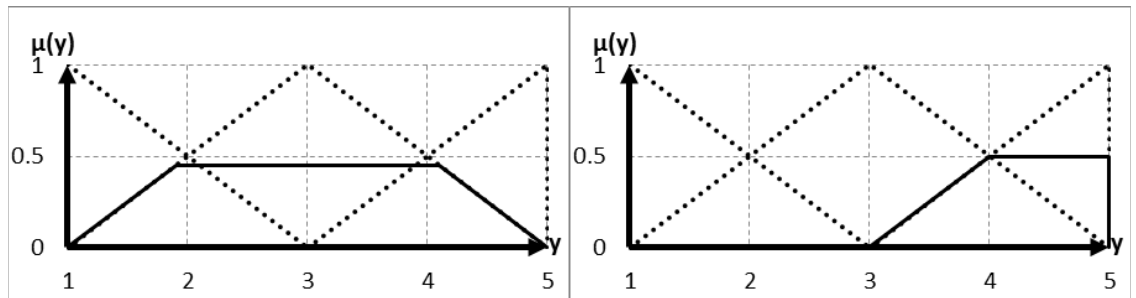

Fig. 6. Modified conclusion membership functions of the first and the second rule; source: own elaboration $\mu_{\mathrm{B} 2^{*}}(\mathrm{y})=\min \left(0.33, \mu_{\mathrm{B} 2}(\mathrm{y})\right)$ $\mu_{\mathrm{B} 2^{*}}(\mathrm{y})=\min \left(0.33, \mu_{\mathrm{B} 2}(\mathrm{y})\right)$
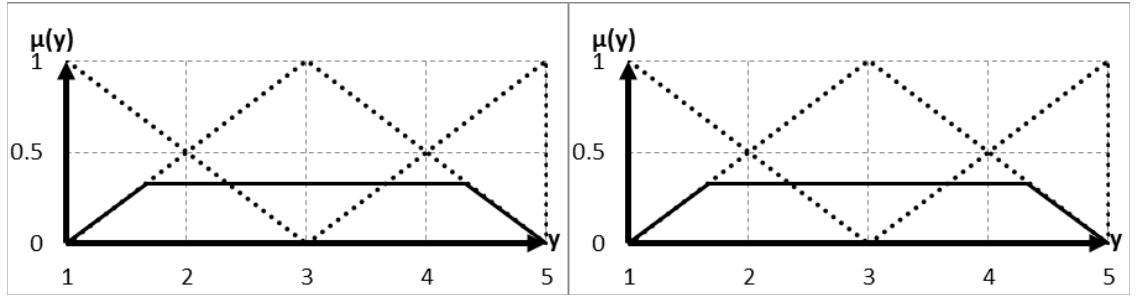

Fig. 7. Modified conclusion membership functions of the third and the fourth rule; source: own elaboration

Determining the resulting membership function $\mu_{\mathrm{wyn}}(\mathrm{y})$ through aggregations of modified membership functions $\mu_{\mathrm{B}^{*}}(\mathrm{y})$ of conclusions of specific rules is presented in Fig. 8 .

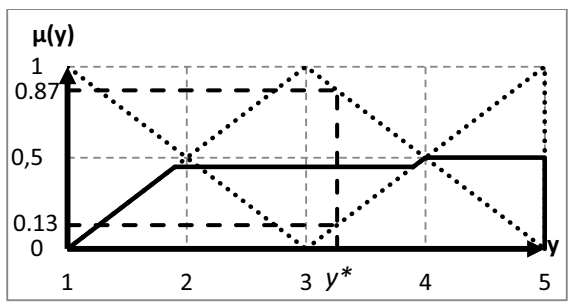

Fig. 8. Resulting membership functions of the output value; source: own elaboration 


\section{Defuzzification}

$$
y^{*}=\frac{\int_{a}^{b} y \cdot \mu_{w y n}(y) d y}{\int_{a}^{b} \mu_{w y n}(y) d y}=3.26
$$

Determining the value of conclusion's membership function in $\mathbf{y}=\mathbf{3 . 2 6}$ :

$\mu_{\mathrm{B} 1}(3.26)=0-$ value of the "keep" conclusion's membership function

$\mu_{\mathrm{B} 2}(3.26)=0.87-$ value of the "improve" conclusion's membership function

$\mu_{\mathrm{B} 3}(3.26)=0.13-$ value of the "improve immediately" conclusion's membership function

\section{Result: Improve}

Analogically, conclusion for the analysed partnering relation parameter is determined in relation to cost, quality and safety. Eventually, the most radical out of the 4 conclusions is chosen.

\section{Conclusions}

The controlling system, the proposal of which has been presented, will be a unique tool supporting the management of construction projects through development of partnering relations between the participants of these projects. As recommendations for management of the project, it will prefer improvement of these partnering relation parameters which provide the highest benefits in terms of time, cost, quality and safety. Thanks to this kind of approach, the purpose of using a partnering approach in management will be highlighted. Furthermore, the parameter to be improved first will be indicated.

It can be observed that the system's operation is directly related to forms of fuzzy sets' membership functions. Therefore, an analysis of the model's sensitivity to changes in the membership functions of fuzzy sets will be performed and the use of different kinds of these - e.g. trapezoid or Gaussian curves - will be considered. Fuzzy logic allows the defining of operators AND and OR in different ways, as well as the defuzzification operator. The impact of the different operators on the obtained conclusions will also be the subject of further research. What is more, the "improve" and "improve immediately" conclusions will be supplemented in the future with examples of actions that could be taken in order to improve the specific partnering relation parameter. 


\section{REFERENCES}

1. R. Bayliss, S. O. Cheung, H. C. H. Suen, S. P. Wong, "Effective partnering tools in construction: a case study on MTRC TKE contract 604 in Hong Kong” International Journal of Project Management, 22, pp. 253-263, 2004.

2. R. Beach, M. Webster, K. M. Campbell, "An evaluation of partnership development in the construction industry" International Journal of Project Management, 23(8), pp. 611-21, 2005.

3. C. Black, A. Akintoye, E. Fitzgerald, "An analysis of success factors and benefits of partnering in construction" International Journal of Project Management, 18, pp. 423-434, 2000.

4. A. P. C. Chan, D. W. M. Chan, K. S. K. Ho, "An empirical study of the benefits of construction partnering in Hong Kong" Construction Management and Economics, 21, pp. 523-533, 2003.

5. T. T. Chen, T. C. Wu, "Construction project partnering using fuzzy based decision making methodology" Journal of the Chinese Institute of Engineers, 35(3), pp. 269-284, 2012.

6. S. O. Cheung, H. C. H. Suen, K. K. W. Cheung, "An automated partnering monitoring system—Partnering Temperature Index" Automation in Construction, 12, pp. 331- 345, 2003.

7. D. Gransberg, W. Dillon, L. Reynolds, J. Boyd, "Quantitative Analysis of Partnered Project Performance" Journal of Construction Engineering and Management, 125(3), pp. 161-166, 1999.

8. A. Kosecki, "Kontraktowanie realizacji serii obiektów budowlanych" Prace Naukowe Instytutu Budownictwa Politechniki Wrocławskiej: Studia i Materiały, 91(20), pp. 89-95, 2008.

9. J. W. E. Masterman, “An Introduction to Building Procurement Systems”, Spon Press, New York, 2002.

10. N. Mingus, „Zarządzanie projektami”, Wydawnictwo Helion, Gliwice, 2002.

11. A. Piegat, "Modelowanie i sterowanie rozmyte", Akademicka Oficyna Wydawnicza EXIT, Warszawa, 2003.

12. E. Radziszewska-Zielina, "Fuzzy control of the partnering relations of a construction enterprise" Journal of Civil Engineering and Management, 17(1), pp. 5-15, 2011.

13. E. Radziszewska-Zielina, B. Szewczyk, "The model of partner relationships' impact on time, cost, quality and safety in construction projects" International Scientific Conference People, Buildings and Environment, 1517.10.2014, Brno University of Technology, Faculty of Civil Engineering, conference proceedings, 3, 2014

14. E. Radziszewska-Zielina, B. Szewczyk, "Analiza regresji pomiędzy poziomem relacji partnerskich a ich wpływem na czas, koszt, jakość i bezpieczeństwo realizacji przedsięwzięć budowlanych” Logistyka, 6, pp. 14631-14639, 2014.

15. E. Strzelecka, B. Glinkowska, M. Maciejewska, B. Wiażel-Sasin, „Zarządzanie przedsięwzięciami budowlanymi. Podstawy, procedury, przykłady”, Wydawnictwo Politechniki Łódzkiej, Łódź, 2014.

16. D. Weston, G. Gibson Jr, "Partnering-Project Performance in U.S. Army Corps of Engineers" Journal of Management in Engineering, 9, pp. 410-425, 1993.

17. J. F. Y. Yeung, A. P. C. Chan, D. W. M. Chan, "A computerized model for measuring and benchmarking the partnering performance of construction projects" Automation in Construction, 18, pp. 1099-1113, 2009. 


\section{LIST OF FIGURES AND TABLES:}

Fig. 1. Membership functions for assessment of partnering relation parameters; source: own elaboration Rys. 1. Funkcje przynależności dla ocen parametrów relacji partnerskich; źródło: opracowanie własne Fig. 2. Membership functions for weights of partnering relation parameters' impact on project assessment criteria; source: own elaboration Rys. 2. Funkcje przynależności dla wag wpływu parametrów relacji partnerskich na kryteria oceny przedsięwzięcia; źródło: opracowanie własne

Fig. 3. Membership functions for weights of project assessment criteria; source: own elaboration Rys. 3. Funkcje przynależności dla wag kryteriów oceny przedsięwzięcia; źródło: opracowanie własne Fig. 4. Membership functions for the output variable; source: own elaboration Rys. 4. Funkcje przynależności dla zmiennej wyjściowej; źródło: opracowanie własne

Fig. 5. Illustration of the fuzzification process for crisp values of input variables; source: own elaboration Fig. 5. Ilustracja procesu fuzyfikacji ostrych wartości zmiennych wejściowych; źródło: opracowanie własne Fig. 6. Modified conclusion membership functions of the first and the second rule; source: own elaboration Rys. 6. Zmodyfikowana funkcja przynależności konkluzji dla pierwszej i drugiej reguły; źródło: opracowanie własne

Fig. 7. Modified conclusion membership functions of the third and the fourth rule; source: own elaboration Rys. 7. Zmodyfikowana funkcja przynależności konkluzji dla trzeciej i czwartej reguły; źródło: opracowanie własne

Fig. 8. Resulting membership functions of the output value; source: own elaboration

Rys. 8. Wynikowa funkcja przynależności zmiennej wyjściowej; źródło: opracowanie własne

Tab. 1. Weights of project assessment criteria in linguistic form and five-point scale; source: own elaboration Tab. 1. Wagi kryteriów oceny przedsięwzięcia w formie lingwistycznej i skali pięciopunktowej; źródło: opracowanie własne 


\section{STEROWANIE RELACJAMI PARTNERSKIMI W PRZEDSIĘWZIĘCIACH BUDOWLANYCH Z WYKORZYSTANIEM WNIOSKOWANIA ROZMYTEGO}

Słowa kluczowe: przedsięwzięcia budowlane, system sterowania, wnioskowanie rozmyte, model Mamdaniego, relacje partnerskie

\section{STRESZCZENIE:}

W artykule zaprezentowano projekt systemu sterowania relacjami partnerskimi w przedsięwzięciach budowlanych. Wskazywał on będzie do poprawy obszary współpracy zarządzającego przedsięwzięciem z wykonawcami (podwykonawcami), projektantem, dostawcami i inwestorem, w których rozwijanie relacji partnerskich przynosi największe korzyści w odniesieniu do czasu, kosztu, jakości i bezpieczeństwa realizacji przedsięwzięć budowlanych. W ramach współpracy zarządzającego przedsięwzięciem z wykonawcami (podwykonawcami), projektantem, dostawcami i inwestorem wyróżniono następujące parametry opisujące relacje partnerskie. W ramach współpracy zarządzającego przedsięwzięciem $\mathrm{z}$ wykonawcami/podwykonawcami są to: udział $\mathrm{w}$ organizacji budowy, dzielenie się zasobami niematerialnymi, materialnymi i ludzkimi, skuteczna komunikacja, przestrzeganie ustalonych standardów i reguł zachowania, dotrzymywanie ustalonych terminów wypłat wynagrodzeń i ich wysokości, częstość występowania sporów i szybkość ich rozwiazywania, elastyczne podejście do zmian. Parametry relacji partnerskich w ramach współpracy zarządzającego przedsięwzięciem z projektantem to: szybkość odpowiedzi na propozycje zmian projektowych, szybkość reagowania na problemy projektowe, dostosowanie rozwiązań projektowych (robót dodatkowych i zamiennych) do możliwości wykonawcy. Parametry relacji partnerskich w ramach współpracy zarządzającego przedsięwzięciem z dostawcami to: zapewnienie jakości materiałów i sprzętu, terminowość dostaw, bieżące wsparcie techniczne. Parametry relacji partnerskich w ramach współpracy zarządzającego przedsięwzięciem z inwestorem to: wypracowanie udogodnień $\mathrm{w}$ zagospodarowaniu placu budowy, dotrzymywanie ustalonych terminów wypłat wynagrodzeń i ich wysokości, dyspozycyjność nadzoru inwestorskiego przy odbiorach, częstość występowania sporów i szybkość ich rozwiazywania. Do opracowania projektu systemu sterowania relacjami partnerskimi wykorzystano model rozmyty, oparty na wnioskowaniu Mamdaniego. Zmiennymi wejściowymi systemu będą: bieżące oceny poszczególnych parametrów relacji partnerskich, wagi wpływu tych parametrów na czas, koszt, jakość i bezpieczeństwo realizacji przedsięwzięć budowlanych oraz ważność czasu, kosztu, jakości i bezpieczeństwa realizacji przedsięwzięcia dla zarządzającego nim. W działaniu systemu sterowania wyróżnić można trzy zasadnicze procesy realizowane dla każdej kombinacji parametru relacji partnerskich i analizowanego kryterium oceny przedsięwzięcia budowlanego (czas, koszt, jakość, bezpieczeństwo). Pierwszym z nich jest proces fuzyfikacji (rozmywania), w którym następuje określenie stopnia przynależności zmiennych wejściowych do zbiorów rozmytych. W artykule przyjęto trójkątne funkcje przynależności zbiorów rozmytych. Następnie w procesie inferencji (wnioskowania) wykorzystuje się bazę reguł i mechanizm wnioskujący w celu obliczenia wynikowej funkcji przynależności zmiennej wyjściowej. Zastosowano operatory AND w postaci funkcji minimum oraz OR w postaci funkcji maksimum. Obliczenia zamyka proces defuzyfikacji (wyostrzania), w wyniku którego otrzymywana jest ostra wartość zmiennej wyjściowej, na podstawie której określana jest konkluzja, stanowiąca zalecenia do sterowania w odniesieniu do konkretnego parametru relacji partnerskich. W artykule do defuzyfikacji zaproponowano metodę środka ciężkości. Konkluzja może przyjmować wskazania: zachowaj, popraw lub popraw natychmiast. Dla każdego z parametrów relacji partnerskich 
otrzymane zostaną zatem 4, po jednej w odniesieniu do czasu, kosztu, jakości i bezpieczeństwa realizacji przedsięwzięcia. Ostatecznie wybierana będzie najbardziej radykalna z 4 konkluzji, gdzie konkluzją najmniej radykalną jest konkluzja zachowaj, a najbardziej radykalną konkluzja popraw natychmiast. Ponadto zostanie wskazany parametr, który należy poprawić w pierwszej kolejności. W artykule zamieszczono przykład obliczeniowy ilustrujący działanie systemu. 